\title{
CD8 + Tumoral as Predictor of Neoadjuvant Chemotherapy Response in Patients with Local Advanced Stage Breast Cancer \\ Muhammad Danar Deswangga ${ }^{1}$, Yamin Alsoph ${ }^{1 *}$
}

${ }^{1}$ Depeartment of Surgery, Faculty of Medicine, Universitas Sriwjaya, Indonesia

*Correspondence Author Email : yaminalsoph@gmail.com

\begin{abstract}
Introduction. Cancer until now has become a problem for health in the world including Indonesia. According to 2013 WHO data, cancer incidence has increased from 12.7 million cases in 2008 to 14.1 million cases in 2012. In local advanced breast cancer the treatment is neoadjuvant chemotherapy. Neoadjuvant therapy usually uses anthracycline or taxane based which can improve chemotherapy responses.

Methods. This type of research is a CD8 + tumoral prognostic test used to predict neoadjuvant chemotherapy responses in patients with locally advanced breast cancer. The research was carried out in the oncology surgery clinic and inpatient Dr. Mohammad Hoesin Hospital Palembang. Assessment of CD8 + expression is done by immunohistochemistry. CD8 + expression is expressed as a percentage of cell expression, whose the cut off point is determined first.

Result. There was a significant relationship between CD8 + tumoral with chemotherapy response $(\mathrm{p}=0.033)$ with a sensitivity value: $43.5 \%$; specificity: $100 \%, \mathrm{NR}+: 100 \%$; NR-: $35 \%$; False positive: $0 \%$; False negative: $65 \%$; OR: 1.53 . CD8 + predominantly had a good chemotherapy response in all samples of $10(100 \%)$ patients while CD8 + non-dominant tumoral was more in a good chemotherapy response with $13(65 \%)$ patients and poor chemotherapy response in 7 (35\%) patient.
\end{abstract}


Conclusion. CD8 + as a predictive factor for neoadjuvant chemotherapy responses in local advanced breast cancer has a significant relationship, with a $\mathrm{p}$ value $=0.033$, sensitivity value: 43.5\%; specificity: 100\%, NR +: 100\%; NR-: 35\%; False positive: 0\%; False negative: $65 \%$.

\section{Keywords: CD8+ tumoral, neoadjuvant chemotherapy response, breast cancer, local advance stage}

\section{Introduction}

Cancer until now has become a problem for health in the world including Indonesia. According to 2013 WHO data, cancer incidence has increased from 12.7 million cases in 2008 to 14.1 million cases in 2012, with the number of deaths increasing from 7.6 million people in 2008 to 8.2 million people in 2012. Cancer has become a cause death number 2 in the world by $13 \% .^{1-3}$ In Dr. Moh Hoesin general hospital Palembang, the number of breast cancer cases in 2013 were 832 breast cancer cases and the most in RSMH was Stage III or local advanced breast cancer (LABC), namely Stage III A $26.53 \%$ and Stage IIIB 48.98\%. ${ }^{4}$ Most breast cancer sufferers in Indonesia treatment in an advanced stage, as seen in the report on the incidence of breast cancer in Dharmais Cancer Hospital according to stadium, namely stage I 6\%, stage II 18\%, stage III $44 \%$, and stage IV $32 \% .{ }^{1}$ Budiningsih et al reported cancer patients most breasts are in stage IIB with a percentage of $40 \%$. According to Surveillance Epidemiology and End Results data in the United States, the 5-year survival rates for stage III and IV breast cancer are only $57 \%$ and $20 \% .^{3}$ Therefore, optimal treatment for patients with local advanced breast cancer survival rates and prevent locoregional recurrence. ${ }^{2}$

In local advanced breast cancer the treatment is neoadjuvant chemotherapy. Neoadjuvant therapy usually uses anthracycline or taxane based which can improve chemotherapy responses. Predictive factors for neoadjuvant chemotherapy responses include size, type, tumor differentiation, HER2Neu and Ki-67. In addition, tumor infiltrative lymphocytes (TILs) are important predictive factors in the chemotherapy response in breast cancer patients. ${ }^{6}$ 


\section{SSS SRIWIJAYA JOURNABOFSURGERУ}

The immune response plays an important role in tumor progression. Tumor infiltrating lymphocytes (TILs) describe a local immune response and can be key in the progressive control mechanism of tumors. A number of studies illustrate that TILs have a relationship with clinical outcomes in cancer patients. TILs are known that most are T lymphocytes and the majority of expression is a cytotoxic effector CD8 + phenotype. ${ }^{7} \mathrm{~T}$ lymphocyte cells have several important functions and are divided into two categories, namely as regulators and effectors. The regulator function is played by $\mathrm{T}$ helper (Th) cells that express surface proteins in the form of CD4 + which play a role in countering microorganisms. While the effector function is played by cytotoxic $\mathrm{T}$ lymphocytes (CTLs) which express the surface protein CD8 +, which plays a role in killing cells

affected by tumors ${ }^{8-15}$. CD $8+\mathrm{T}$ cytotoxic $\mathrm{T}$ lymphocyte cells (CTL s) are cells that secrete molecules that damage cells that have been bound to antigens. This is a very useful function if the target cell is infected with a virus because the cell is usually destroyed before it can release virus products that can infect other cells. There is a relationship between TILs and neoadjuvant chemotherapy responses where dominant TILs can be predictors with an 8 times chance of getting a good chemotherapy response. $66.7 \%$ sensitivity, $80 \%$ specificity, positive predictive value 95.2\%, negative predictive value $28.6 \%$ and accuracy of $68.5 \%$ TILs in predicting neoadjuvant chemotherapy responses in Stage IIIB Breast Carcinoma CD8 + cytotoxic T lymphocytes are an important component of TILs that is related to the chemotherapy response and can be used as a predictor of response to anthracycline or anthracycline / taxane based on breast cancer. ${ }^{17}$ According to Ady et al, states that cellular immunity, represented by CD8 + CTL, has anti-tumor activity, and can used as an immunotherapy tool to improve the prognosis of breast cancer patients, especially the biological subtypes of poor prognosis. ${ }^{18}$

\section{Methods}

This type of research is a CD8 + tumoral prognostic test used to predict neoadjuvant chemotherapy responses in patients with locally advanced breast cancer. The research was carried 


\section{SSS SRIWIJAYA JOURNABOFSURGERУ}

out in the oncology surgery clinic and inpatient Dr. Mohammad Hoesin Hospital Palembang. The study sample (30 research subjects) were all local advanced breast cancer patients who met the inclusion and exclusion criteria. Inclusion criteria are local advanced stage breast cancer patients determined based on the criteria of the American Joint Committee of Cancer, will undergo neoadjuvant chemotherapy, have a Karnofsky index $\geq 50$, are willing to participate in research and sign informed consent. Exclusion criteria was patients who had undergone chemotherapy before, or immunocompromised condition.

Sociodemographic exploration of the research subjects included age, marital status, history of contraception. Chemotherapy response assessment is done by assessing the reduction in tumor mass size compared to before chemotherapy. If there is a reduction in the size of the tumor diameter is considered a good response, whereas if there is no reduction in the size of the tumor is categorized as a bad response. Assessment of CD8 + expression is done by immunohistochemistry. CD8 + expression is expressed as a percentage of cell expression, whose the cut off point is determined first.

Data was collected by coding and tabulating as well as data entry into the computer. Data analysis includes descriptive analysis and hypothesis testing. In the descriptive analysis of numeric data expressed in mean \pm standard deviation while categorical data expressed in numbers and percentages. Primary analysis was performed to assess intratumoral CD8 + levels in estimating neoadjuvant chemotherapy responses in patients with locally advanced breast cancer. The probability of chemotherapy response both as a functional parameter is determined through multivariate and bivariate analysis. The significance level was p $<0.05$ with an $80 \%$ confidence interval. The data in this study will be presented in tabular form and analyzed using SPSS version 23.

\section{Results}

Most of the study samples were aged over 40 years as many as $25(83.3 \%)$ patients and 5 patients under the age of 40 years (16.7\%) patients. Almost all samples have married status as many as $29(85.3 \%)$ patients and 22 (73.3\%) patients have family planning. In clinical characteristics, the majority of samples followed the type of chemotherapy TAC in 18 (60\%) 


\section{STS SRIWIJAYAJOURNAB OFEURGERY}

patients while the sample that followed the FAC / TC were $12(40 \%)$ patients. $23(76.7 \%)$ patients received a good chemotherapy response while 7 (23.3\%) patients received a bad response.

Table 1. Baseline Characteristics Research Subject

\begin{tabular}{|c|c|c|}
\hline Variable & $\mathrm{N}$ & $\%$ \\
\hline \multicolumn{3}{|l|}{ Age } \\
\hline$>40$ years & 25 & 83.3 \\
\hline$<=40$ years & 5 & 16.7 \\
\hline \multicolumn{3}{|l|}{ Marital status } \\
\hline Married & 29 & 96,7 \\
\hline Single & 1 & 3,3 \\
\hline \multicolumn{3}{|l|}{ Contraception } \\
\hline Yes & 22 & 73,3 \\
\hline No & 8 & 26,7 \\
\hline \multicolumn{3}{|l|}{ Chemotherapy type } \\
\hline $\mathrm{TAC} / \mathrm{TC}$ & 12 & 40 \\
\hline FAC & 18 & 60 \\
\hline \multicolumn{3}{|l|}{ Chemotherapy response } \\
\hline Good & 23 & 76,7 \\
\hline Poor & 7 & 23,3 \\
\hline
\end{tabular}

In finding the Cut Off Point percentage of CD8 + expression, it was done by finding the area under curve (AUC) value, sensitivity value, specificity, positive predictive value, positive false value, negative predictive value, negative false value, confidence interval (CI) and odd ratio (OR). 


\section{SSS SRIWIJAYAJOURNABOPSURGERУ}

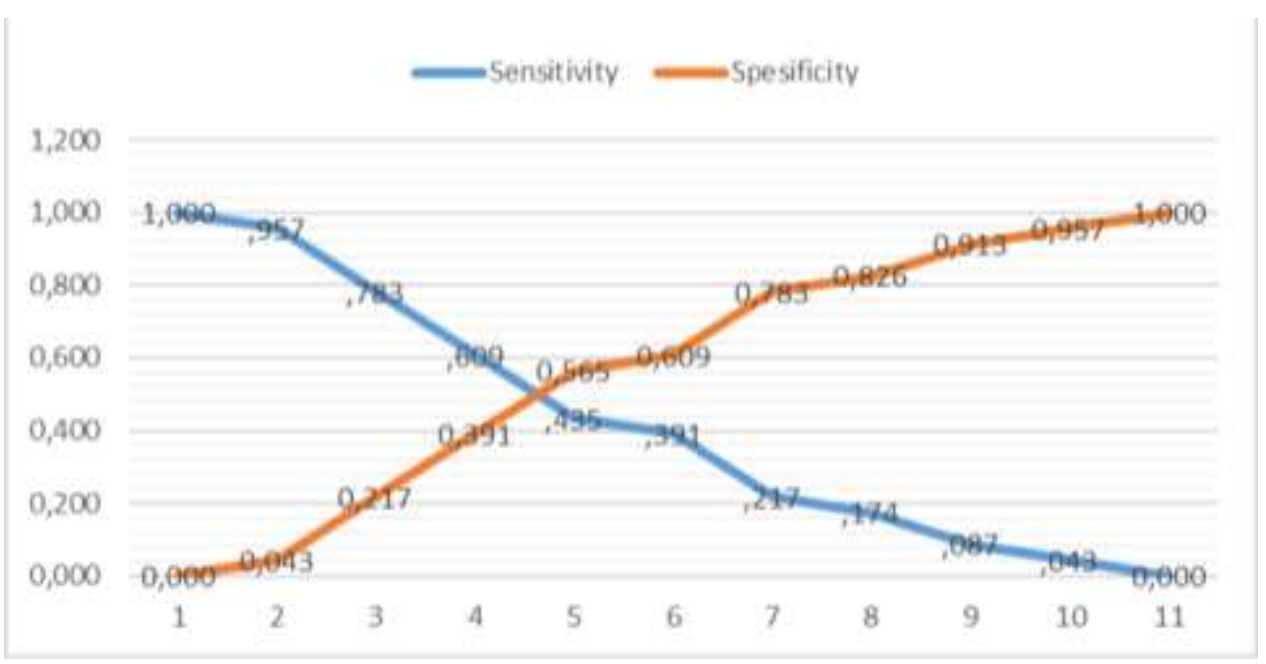

Figure 1. CD8+Cut Off Point

Based on the cut off point value in figure 1, the point at number 4.5 is obtained, then the value at line 4.5 is between row 4 and line 5 . In order to get the value $(7.50+12.50) / 2=10 \%$ with a sensitivity value of $52 \%$ and specificity $47.8 \%$. After the cut-off point value is $10 \%$, the results from the category on CD8 + are divided into dominant with a value of $>10 \%$ and not dominant is rated $\leq 10 \%$ and chi square analysis is performed to see the relationship between CD8 + with chemotherapy response which can be seen in Table 8 there was a significant relationship between CD8 + tumoral with chemotherapy response $(\mathrm{p}=0.033)$ with a sensitivity value: $43.5 \%$; specificity: 100\%, NR +: 100\%; NR-: 35\%; False positive: 0\%; False negative: 65\%; OR: 1.53. CD8 + predominantly had a good chemotherapy response in all samples of 10 (100\%) patients while CD8 + non-dominant tumoral was more in a good chemotherapy response with $13(65 \%)$ patients and poor chemotherapy response in $7(35 \%)$ patients .

Table 2. Relationship between CD8 + with Therapeutic Response

\begin{tabular}{rccccc}
\hline & & \multicolumn{2}{c}{ Chemotherapy response } & Total & p* \\
\cline { 3 - 4 } & & Good & Poor & & \\
\hline CD8 $^{+}$ & Dominant $(>10 \%)$ & $10(100 \%)$ & $0(0.0 \%)$ & $10(100 \%)$ & 0.033 \\
& Non Dominant $(\leq 10 \%)$ & $13(65 \%)$ & $7(35 \%)$ & $20(100 \%)$ & \\
& Total & $23(76.7 \%)$ & $7(23.3 \%)$ & $30(100 \%)$ & \\
\hline
\end{tabular}




\section{STS SRIWIJAYA JOURNAB OFEURGERY}

*Chi-square test, significant if $\mathrm{p}<0.05$, OR: 1,53 (95\% CI: $1.15-2.12)$

\section{Discussion}

The incidence of breast cancer increases with age, every ten years, the risk of cancer increases twice until the age of menopause. In this study, the majority of the sample of this study were aged over 40 years as many as $25(83.3 \%)$ patients and 5 patients under the age of 40 years (16.7\%) patients. Almost all samples were married as many as 29 (96.7\%) patients. A study showed the average age of breast cancer patients was $45.83 \pm 11.05$ where more patients $\geq 45$ years $(58 \%)$ were found than patients aged $<44$ years $(42 \%) .{ }^{19}$ History of hormonal contraception in breast cancer patients in this study were $22(73.3 \%)$ This result is in line with a study in which breast cancer patients with a history of hormonal contraception were $74.5 \% .{ }^{20}$ In this study most of the samples followed the FAC chemotherapy type in 18 (52.9\%) patients and then in the sample that followed TAC in $7(20.6 \%)$ patients and TC in $5(14.7 \%)$ patients. $23(76.7 \%)$ patients received a good chemotherapy response while 7 (23.3\%) patients received a bad response.

In this study the CD8 + cut-off point was at $10 \%$ with a sensitivity value of $52 \%$ and specificity of $47.8 \%$. So that the CD8 + classification is dominant at> $10 \%$ and non-dominant is at dinilai $10 \%$. Of all anatomic pathology factors such as tumor type histopathologically, LVI, TIL, CD8 +, ER, PR, HER2, triple negative and Ki67 only TIL and CD8 + have a significant relationship with chemotherapy response. Given that there are no clinically determined cutoff points for these numbers TIL (CD4 +, CD8 +, gd, and FOXP3 + T cells) in tumor tissue, a study in line with this study determined cut-off values based on the area under curve, median value and hazard ratio 21. $\mathrm{CD} 8+$ as a chemotherapy response has a sensitivity value: $43.5 \%$; specificity: $100 \%, \mathrm{NR}+: 0 \%$; NR-: 35\%; False positive: 100\%; False negative: $65 \%$. TIL as a chemotherapy response has a sensitivity value: $87 \%$; specificity: $71.4 \%$, predictive value (NR) positive: $90 \%$; NR NR negative: 62.5\%; False positive: $9.1 \%$; False negative: $37.5 \%$. In local advanced breast cancer the treatment is neoadjuvant chemotherapy. Neoadjuvant therapy usually uses anthracycline or taxanes-based which can improve chemotherapy responses. Predictive factors for neoadjuvant chemotherapy responses include size, type, tumor differentiation, HER2Neu and Ki-67. In addition, tumor infiltrative lymphocytes (TILs) are an important predictive factor in chemotherapy responses in 


\section{SSS SRIWIJAYA JOURNABOFSURGERУ}

breast cancer patients. $^{22}$ A study obtained from multivariate analysis, CD $8+$ showed strong prognostic significance for chemotherapy responses, with hazard ratio (HR) 3.09 (HR) 3.09 (hazard ratio) $95 \%$ confidence interval $(\mathrm{CI}) 1,537-6,614, \mathrm{P}=0.0013$ ). The $\mathrm{CD} 8 / \mathrm{FOXP} 3$ ratio also correlated significantly with disease-free survival $(\mathrm{HR}=2.07,95 \% \mathrm{CI} 1.029-4.436, \mathrm{P}=$ 0.0412). A high CD8 + TIL level is a very strong indicator of increased survival specifically for breast cancer patients (BCSS), with a hazard ratio (HR) of 3.59 (95\% CI 1,499-9,581, P = 0.0036). Nodal status was also associated with BCSS $(\mathrm{P}=0.0024) .{ }^{23}$

Other studies obtained results among 3403 immunohistochemical cases obtained, CD8 + lymphocyte infiltration tumors were identified in intratumoral patterns in $32 \%$ and stromal patterns in $61 \%$ cases. In the cohort analysis, the presence of tumor-infiltrating intratumoral lymphocytes was significantly correlated with young age, high risk, negative ER, positive Her2Neu and in intrinsic basal like subtypes. Multivariate analysis showed that the beneficial prognostic effect of CD8 + lymphocyte infiltration tumors was only significant in the basal-like subgroup (hazard ratio, $\mathrm{HR}=0.35,95 \% \mathrm{CI}=0.23-0.54)$. There was no association with increased survival in patients with triple-breast cancer $(\mathrm{HR}=0.99,95 \% \mathrm{CI}=0.48-2.04)$ or in other intrinsic subtypes. ${ }^{24}$ There was an association between TILs and neoadjuvant chemotherapy responses in which TILs the dominant can be a predictor with a chance 8 times to get a good chemotherapy response. $66.7 \%$ sensitivity, $80 \%$ specificity, positive predictive value $95.2 \%$, negative predictive value $28.6 \%$ and accuracy of 68.5\% TILs in predicting neoadjuvant chemotherapy responses in Stage IIIB Breast Carcinoma CD8 + cytotoxic T lymphocytes are an important component of TILs that is related to the chemotherapy response and can be used as a predictor of response to anthracycline or anthracycline / taxane based on breast cancer. Cellular immunity, represented by CD8 + CTL, has anti-tumor activity, and can be used as an immunotherapy tool to enhance prognosis of breast cancer patients, especially biological subtypes of poor prognosis. ${ }^{29}$

\section{Conclusion}

CD8 + as a predictive factor for neoadjuvant chemotherapy responses in local advanced breast cancer has a significant relationship, with a $\mathrm{p}$ value $=0.033$, sensitivity value: $43.5 \%$; specificity: 100\%, NR +: 100\%; NR-: 35\%; False positive: 0\%; False negative: 65\%; 


\section{SIS SRIWIJAYA JOURNAB OFEURGERY}

\section{References}

1. Levinson W., JawetzE., MedicalMicrobiology \& Immunology $7^{\text {th }}$ edition, McGraw Hill Boston (2003)

2. Pusat Data dan Informasi Kemenkes RI. Situasi Penyakit Kanker dalam Buletin Jendela Data \& Informasi Kesehatan. September 2015 ; hal 2-3

3. Komite Penanggulangan Kanker Nasional. Panduan Penatalaksanaan Kanker Payudara. 2016

4. Ade,Y. Gambaran Penderita kanker payudara usia Muda di RSUP Dr Mohammad Hoesin palembang, 2014

5. Shuzen Liu, Jonathan Lachapelle, Samuel Leung. $\mathrm{CD}^{+}$Lymphocite Infiltration is an Independent Favorable Prognostik Indicator in Basal-like Breast Cancer. Breast Cancer Research. $2012:$ 14/2/R48

6. Muchlis Ramli. Update Breast Cancer Management Diagnostic and Treatment. Majalah kedokteran Fakultas Kedokteran 2015 : vol. 38

7. Khotimah S, Gondhowiardjo SA, Poetiray EC, Djoerban Z. Kemoradiasi Neoajuvan pada Kanker Payudara Lanjut Lokal. Radioterapi \& Onkologi Indonesia. 2011; 2(1):1-4.

8. Ahmed M Kabel, Fahad. H Baali. Breast Cancer : Insight into Risk Factors, Pathogenesis, Diagnosis and Management. Journal of Cancer Research and Treatment. 2015 : vol 3 : 28-33

9. Panduan Penatalaksanaan Kanker Payudara. PERABOI 2010. Jakarta.

10. Page R dan Takimoto. C, Principles of Chemoterapy. Cancer Management : A multidisciplinary approach Medical Surgical dan Radiation Oncology. 2004 : 21-38

11. Vincent T. De Vita. Principles of Cancer Chemoterapy in: Physicians cancer chemoterapy drug manual. 2008

12. Ping Tang MD, Gary .M. Imunohistochemical Surrogates for Molecular Classification of Breast Carcinom. 2015 : vol 140

13. Abul Abbas, Andrew H. Lichtman. Cellular and Molekular Immunology $6^{\text {th }}$ ed. 2010

14. Ashley Cimino and Mathews A. Immune Targeting in Breast Cancer. Jounal of Oncology 2015 : vol. 29

15. Bratawidjaya K G. Imunologi Dasar Edisi ke-10. Jakarta: Badan Penerbit Fakultas Kedokteran Universitas Indonesia; 2012. 


\section{STS SRIWIJAYA JOURNAB OFEURGERY}

16. American Joint Committee on Cancer. Breast Cancer Staging $7^{\text {th }}$ Edition. 2010. Available at: https://cancerstaging.org/referencestools/quickreferences/Documents/BreastMedium.pdf, accessed 3 Mar 2017.

17. Ashley Cimino and Mathews A. Immune Targeting in Breast Cancer. Jounal of Oncology 2015 : vol. 29

18. Buchholz TA, Hunt KK, Whitman GJ, Sahin AA, Hortobagyi GN. Neoadjuvant Chemotherapy For Breast Carcinoma: Multidisciplinary Considerations of Benefits and Risks. Cancer. 2003; 98(6):1150-1160

19. Elmore, S. Apoptosis: a review of programmed cell death. Toxicology Pathology. 2007, 35(4): 495-516

20. Ramli M. Update Breast Cancer Management Diagnostic and Treatment. Majalah Kedokteran Andalas. 2015; 38 (Supl1): 1-26.

21. Purwanto H, Handojo D, Haryono SJ, Harahap WA, editor. Terapi Dalam: Panduan Penatalaksanaan Kanker Payudara.

22. Sukardja, 2000, Onkologi Klinik, Edisi kedua, Surabaya, Erlangga University press.

23. Dushyanthen S, Beavis PA, Savas P, Teo ZH, Zhou CH et al. Relevance of tumor-infiltrating lymphocytes in breast cancer. BMC Medicine. 2015; 13: 1-13.

24. Ahn SG, Jeong J, Hong SW, Jung WH. Current Issues and Clinical Evidence in TumorInfiltrating Lymphocytes in Breast Cancer. Journal of Pathology and Translational Medicine 2015; 49: 355-363

25. Ali hr, Association between CD8+ T-cell infiltration and breast cancer survival in 12,439 patients. 2014 Aug;25(8):1536-43

26. Kusuma Ishak, Akurasi Tumor infiltrating lymphocytes sebagai prediktor respon kemoterapi neoadjuvan pada karsinoma payudara stadium IIIb. 2018

27. Seo AN,et al. Tumor Infiltrating CD8+ lymphocytes as an independent predictive factor for pathological complete response to primary systemic therapy in breast cancer. British Journal Cancer.2013. 109;27052713

28 David Hassin,et al. Cytotoxic T lymphocyte perforin and Fas ligand working in concert even when Fas ligand lytic action is still not detectable 


\section{SSS SRIWIJAYA JOURNAB OFEURGERY}

29.Ady prayitno,et al. Lymphocytes CD8+ Expression Mean Increases the Immunity against

Cancer. Journal of Immune Based Therapies, Vaccines and Antimicrobials, 2014, 3, 37-41 